\title{
PERDE VE ÇERÇEVELİ BETONARME YAPILARDA PERDE KONUMUNUN PLANDA DÜZENLENMESİ VE YAPISAL DAVRANIŞA ETKİSI
}

\author{
Gökhan KAYA1, Ayșe Elif ÖZSOY ÖZBAY2*
}

\author{
${ }^{1}$ Beykent Üniversitesi, Fen Bilimleri Enstitüsü, İnşaat Mühendisliği AB Dalı, İstanbul, Türkiye \\ 2 Maltepe Üniversitesi, Mühendislik ve Doğa Bilimleri Fakültesi, İnşaat Mühendisliği Bölümü, İstanbul, Türkiye
}

\begin{tabular}{|c|c|}
\hline Anahtar Kelimeler & Öz \\
\hline $\begin{array}{l}\text { Cerçeve sistemler, } \\
\text { Cok katlı betonarme yapılar, } \\
\text { Perdelerin planda yerleşimi, } \\
\text { Taşlyıcı sistem. }\end{array}$ & 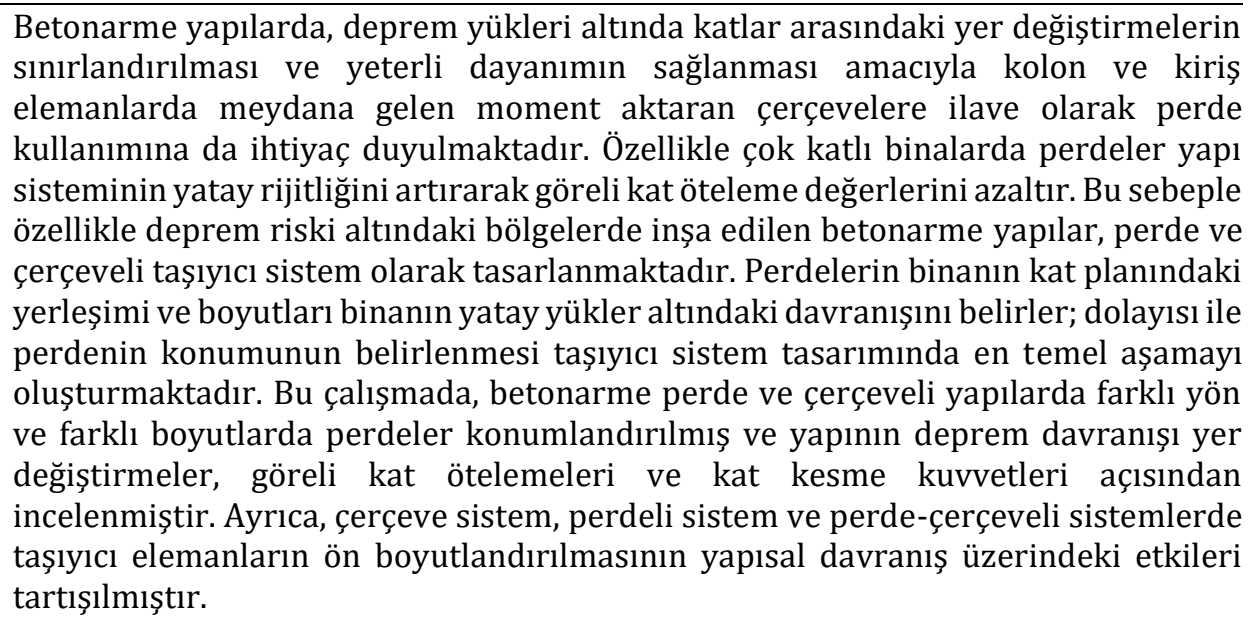 \\
\hline
\end{tabular}

\section{SHEAR WALL LAYOUT IN PLAN OF REINFORCED CONCRETE FRAMED BUILDINGS AND THE EFFECT ON STRUCTURAL BEHAVIOR}

\begin{abstract}
Keywords
Frameds Structures, Multistory reinforced concrete structures, Shear wall layout in plan, Structural system.
\end{abstract}

\begin{abstract}
Shear walls in reinforced concrete buildings are the most necessary structural members for framed structures especially for the ones existing at the regions with seismic risk in order to provide the lateral strength and stiffness and to reduce the interstory drift ratio. Thus, the structural system for a multistory reinforced concrete buildings located on seismic regions should be designed as framed structures with shear walls. The shear wall layout and the dimensions on the plan view play a key role on the seismic behaviour of the framed structure, hence the decision on the location of shear walls for the framed structures is the main step for the preliminary structural system design. This study aims to investigate the effect of shear wall layout in the plan view of reinforced concrete buildings on the seismic response parameters as story shear, lateral displacements and interstory drift ratio. The finite element analyses of the alternative structure models with different orientations, locations and dimensions of shear walls in plan view have been conducted for a seven story framed structure to understand the effect of structural system configuration on seismic response of the reinforced concrete buildings.
\end{abstract}

Alıntı / Cite

Kaya G., Özsoy Özbay A.E., (2019). Perde ve Çerçeveli Betonarme Yapılarda Perde Konumunun Planda Düzenlenmesi Ve Yapısal Davranışa Etkisi, Mühendislik Bilimleri ve Tasarım Dergisi, 7(1), 7-17.

Yazar Kimliği / Author ID (ORCID Number) $\quad$ Makale Süreci / Article Process

G. Kaya, 0000-0003-0371-4802

A. E. Özsoy Özbay, 0000-0001-5397-398X

Başvuru Tarihi / Submission Date

07.06.2018

Revizyon Tarihi / Revision Date

02.09.2018

Kabul Tarihi / Accepted Date

01.11 .2018

Yayım Tarihi / Published Date

25.03.2019

\footnotetext{
* ilgili yazar / Corresponding author: ayseelifozsoyozbay@maltepe.edu.tr
} 


\section{Giriş}

Aktif fay hatları üzerinde yer alan ülkemizde depreme dayanıklı yapı tasarımı, mevcut yapıların deprem davranışının değerlendirilmesi, deprem sonrasında yapılarda meydana gelen hasarın belirlenmesi ve onarımı yapı mühendisliğinin temel çalışma ve araștırma konularıdır.

Mevcut bir yapının deprem davranışı depremin şiddetine, yapının yer aldığı deprem bölgesine, zemin koşullarına ve yapının özelliklerine göre değişmektedir. Yapılarda deprem güvenliğinin sağlanmasında en önemli aşamalar taşıyıcı sistemin doğru seçilmesi, tașıyıcı elemanların en iyi şekilde düzenlenmesi ile birlikte inșa sürecindeki uygulamalar ve malzeme kalitesi olarak sıralanabilir. $\mathrm{Bu}$ kapsamda güvenli bir yapı inşa edebilmek için inşaat mühendislerinin en önemli kaynakları ülkemizde geçerli olan yapısal tasarım standartları ve deprem yönetmeliğidir. Türk Deprem Yönetmeliği kapsamındaki hedefler; hafif düzeydeki depremde yapısal ve yapısal olmayan elemanlarının hasar almaması, orta düzey depremde tüm elemanlarda sınırlı düzeyde hasar; şiddetli depremde ise can güvenliğinin sağlanması ve kalıcı hasarların sınırlandırılması olarak belirtilir (DBYBHY,2007).

Taşıyıcı sistemin tasarımında en önemli hedef, yapısal tasarım, işçilik ve malzeme açısından en uygun maliyet ile yapının maruz kaldığı yükleri en güvenli şekilde zemine aktarmasıdır. Bu bağlamda, taşıyıcı elemanların belirlenmesi, ön boyutlandırması, planda ve düşeyde elemanların yerleşimi bir yapının projelendirilmesi sürecinde en önemli mühendislik problemini oluşturur.

Tasarlanan yapının kullanım amacı, zemin koşulları ve maliyeti dışında yapı yüksekliği ve açıklıklar taşıyıcı sistemin planlanması aşamasında göz önüne alınan etkenler arasındadır. Deprem riskli bölgelerde, artan yapı yüksekliği dayanım ile birlikte yapının yatay rijitliğini ve yatay yükler altındaki dinamik davranışını daha önemli bir noktaya taşımaktadır. Özellikle betonarme yapılarda ülkemizde en yaygın yapı türü olan çerçeve sistemlerde yeterli yatay rijitliğin sağlanamaması, büyük yerdeğiștirmelere ve buna bağlı yapısal hasarlara sebep olabilmektedir (Celep, 2013). Bu sebeple perde ve çerçeveli sistem seçimi ile yapının yatay rijitliği artırılarak yatay yer değiștirmeler sinırlandirılır.

$\mathrm{Bu}$ çalışmada, perde ve çerçeve sistemler ile teşkil edilmiş olan yapılarda perdenin plandaki yerleşimi ve boyutunun yapısal davranışa olan etkisi araştırılmıştır. $\mathrm{Bu}$ amaç ile, perdenin plandaki yerleșiminin farklılık gösterdiği 10 farklı yapısal model "Eşdeğer Deprem Yükü Yöntemi" (DBYBHY, 2007) ile analiz edilmiștir. Modellerde farklı doğrultuda ve boyutta perdeler çerçeve sisteme dâhil edilmiş ve analizler titreşim periyodu, kesme kuvvetleri, yatay yer değiştirme ve göreli kat ötelemesi gibi yapısal parametreler açısından incelenmiştir (Kaya, 2018).

\section{Perde-Çerçeveli Sistemler}

Perdelerin kesit alanları ve eğilme rijitlikleri yapı üzerindeki yatay yükün önemli bölümünü taşımakla birlikte kat yer değiştirmelerinin ve ikinci mertebe etkilerinin sınırlandırılması açısından özellikle çok katlı yapılarda kullanımı kaçınılmaz olmaktadır (DBYBHY, 2007). Kolon ve kirişlerden oluşan moment aktaran çerçeveler ülkemizdeki en yaygın tașıyıcı sistem türüdür. Ancak deprem riskinin yüksek olduğu bölgelerde bina yüksekliğinin artışı ile betonarme çerçevelerde rijitliğin ve dayanımın artırılması ve göreli kat ötelemelerinin belirtilen sınırlar altında tutulabilmesi için perdeye gereksinim duyulmaktadır.

Perde ve çerçevelerin yatay yükler altındaki yerdeğiştirmeleri karşılaştırıldığında perdenin düşey bir konsol kirişe benzer şekilde şekil değiştirdiği ve en büyük göreli kat ötelemesinin en üst katta; çerçeve sistemde ise en büyük değerin genellikle alt katlarda meydana geldiği gözlemlenmiştir. Çerçeve ve perdelerin birlikte kullanıldığı sistemlerde yapıya etkiyen yatay yükün alt katlarda perde; üst katlarda ise çerçeve tarafından taşındığı belirtilmektedir (Aka, vd., 2001).

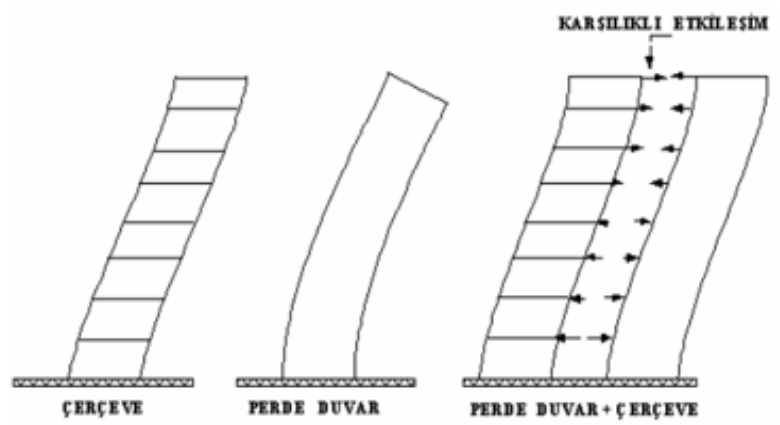

Şekil 1. Çerçeve ve perdenin yatay yükler altında etkileşimi (Özsoy ve Özgen, 2005)

Az katlı yapılar için, perde duvarlı betonarme binalarda yapım maliyeti çerçeve sistem ile karşılaştırıldığında daha yüksek olması ve çerçeve sisteme göre sünekliğinin daha düşük olması perdeli sistemlerin zayıf tarafı olarak belirtilmektedir (Doğangün, 2016). Bunun yanı sıra perdeli sistemlerin deprem yükü altında elastik enerji tüketimi çerçeveye göre daha yüksektir.

Yatay yükler altında düşey taşıyıcıların ön boyutlandırması, taşıyıcı sistem tasarımının ilk adımıdır. Ersoy'un deprem yükleri altında betonarme yapılar için önerdiği ön tasarım yöntemi (Ersoy, 2013), birinci ve ikinci deprem bölgelerinde 
bulunan 2-8 katlı konut ve işyeri amaçlı yapıların eleman boyutlandırması için geliştirilmiştir. Şiddetli bir depremde can kaybını önlemek amacı ile geliștirilen yöntemde, boyutlama ve detaylandırma ile ilgili minimum koşullar esas alınmıștır. Perde ve çerçeve sistemde, taban kesme kuvvetinin \%50'sinin çerçeve tarafından taşınması, perdelerin ise çerçevenin katkısını gözetmeksizin yatay yükün tümünü taşıyabilecek şekilde boyutlanması öngörülmüştür.

Taşıyıcı sistem tasarımında ikinci önemli adım ise, boyutlanan kolon ve perdelerin yapıda düzensizlik oluşmayacak şekilde konumlandırılmasıdır. Uçar, vd. (2014), çerçeve sistem ile teşkil edilmiş yedi katlı mevcut bir betonarme yapıyı güçlendirme kapsamında planda üç farklı düzenleme ile perde ilave etmiş; güçlendirme seçenekleri binanın modal parametreleri ve yerdeğiştirme değerleri açısından değerlendirmiştir. $\mathrm{Bu}$ çalışmada, perde düzenlemesinde burulma açısından planda simetri gözetilmiş; planda ilave edilen perdelerin ilave edildikleri doğrultuda titreşim periyodunu düşürdüğü ve yapıyı rijitleştirdiği tespit edilmiştir. Ayrıca, ilave edilen perdenin kesit alanı ile orantılı olarak perde doğrultusunda göreli kat ötelemelerinde düşüş gözlemlenmiştir.

Işık vd.'nin konu ile ilgili çalışmasında (2017), malzeme ve taşıyıcı sistem seçiminin yapısal performansa olan etkisi; taban kesme kuvveti, yapısal periyot ve tepe yerdeğiştirmesi açısından incelenmiştir. Çalışma kapsamında, seçilen betonarme bir yapı, çerçeve sistem, yapının bodrum katına ilave edilen perdeli sistem ve perde-çerçeveli sistem olarak modellenmiş; değişken malzeme özellikleri ile hesaplamalar gerçekleștirilmiştir. Hesaplamalar sonucunda, artan malzeme dayanımı ve perde duvar kullanımı ile yapisal periyodun azaldığı ve taban kesme kuvvetinin arttığı gözlemlenmiştir.

Gürbüz vd.'nin mevcut bir yapının 2007 Türk Deprem Yönetmeliği'ndeki Deplasmana Dayalı Yöntem ile güçlendirmesi ile ilgili çalışmasında (2013); perde duvarların sisteme ilave edilmesi ile şekildeğiştirme taleplerinin kapasitelerin altına çekildiği; binanın her iki doğrultusunda taban kesme kuvveti kapasitesinde ciddi artış sağlandığı ve mevcut yapının zemin katta yüksek olan göreli kat ötelemelerinin güçlendirme sonrası büyük ölçüde azaldığı belirtilmektedir. Bu çalışmalara ilave olarak, perde ve çerçeve sisteme sahip betonarme yapıların deprem davranışı ve taşıyıcı sistem düzenlemesi ile ilgili pek çok araştırma bulunmaktadır (Koç vd. 2009; Aktan vd. 2010).

$\mathrm{Bu}$ çalışma kapsamındaki yapısal modellerde burulma düzensizliği oluşmayacak şekilde tüm perde yerleşim alternatifleri, plan geometrisine göre simetriktir. Projelendirme öncesi taşıyıcı elemanların düzenlenmesi aşamasında, perde yerlerinin simetrik ve dengeli biçimde seçilmesi, yapının planda her iki doğrultusunda sağlanması gereken temel bir tasarım ilkesidir (Celep, 2013).

Türkiye Bina Deprem Yönetmeliği'nde (2018) taşıyıcı sistemde olumsuz davranışlara yol açan burulma düzensizliği ortadan kaldırarak yeterli burulma dayanımının ve rijitliğin sağlanması esastır. $\mathrm{Bu}$ doğrultuda taşıyıcı sistem elemanlarının olabildiğince binanın çevresine düzenlenmesi gerektiği vurgulanmıştır (TBDY, 2018). Bu sebeple, oluşturulan tüm model alternatiflerinde perdeler yapının cephelerine yerleştirilmiştir.

\subsection{Perdeli ve Perdeli-Çerçeveli Sistemler için Taşıyıcı Sistem Davranış Katsayısı'nın Hesabı}

Deprem Yönetmeliği'nde bulunan “Eşdeğer Deprem Yükü Yönemi"nde yapıya etkiyen taban kesme kuvveti hesabında Toplam Eşdeğer Deprem Yükü Taşıyıcı Sistem Davranış Katsayısı R'ye bağlı olarak azaltılmaktadır. Yönetmelikte tanımlanan değerler, taşıyıcı sistemi ve malzemeyi esas alarak süneklik düzeyi yüksek ve normal seviyeler için belirtilmiştir. Örneğin Süneklik Düzeyi Yüksek yapılarda; yerinde dökme betonarme çerçevelerde $\mathrm{R}=8$ değeri önerilirken; tamamen boşluksuz perdeler ile teşkil edilen sistemlerde $\mathrm{R}=6$ alınmaktadır (DBYBHY, 2007).

Deprem Yönetmeliği'ne göre; boşluksuz betonarme perdeler ve çerçeveler ile teşkil edilen sistemlerde $\alpha_{S}=V_{\text {perde }} / V_{\text {Taban }} \leq 0,75$ koşulu sağlandığ $\mathrm{R}=7$ değeri kullanılabilir. $\alpha_{\mathrm{S}}$ katsayısı perdenin tabanında meydana gelen kesme kuvvetleri toplamının binanın toplam taban kesme kuvvetine oranı olarak tanımlanmaktadır. Bu katsayı, 0,75 1.00 aralığında ise $R=\left(10-4 \alpha_{s}\right)$ bağıntısı ile hesaplanmalı ve bulunan yeni değer ile yapısal analiz tekrar yapılmalıdır (Darılmaz, 2012).

1998 Deprem Yönetmeliği'nde ise perdenin katkısını gösteren $\alpha_{\mathrm{S}}$ katsayısı hesabı perde taban momentleri değerlerine göre yapılmaktaydı (ABYYH, 1998). Gülay vd. (1999) perde ve bina taban momentlerine bağlı hesaplanan perde katkı katsayısı $\alpha_{\mathrm{M}}$ için bağlantılı, bağlantısız ve boşluklu perdeli yapı örnekleri üzerinde parametrik bir çalışma gerçekleştirmiştir. $\mathrm{Bu}$ çalışmada, burulma düzensizliği olan yapılarda, bağ kirişi uçlarında depremden meydana gelen kesme kuvvetlerine bağlı ilave momentlerin $\alpha_{\mathrm{M}} \mathrm{e}$ olan etkisinin burulma düzensizliği bulunmayan yapılara göre \%10-17 daha fazla olduğu belirtilmiştir. 


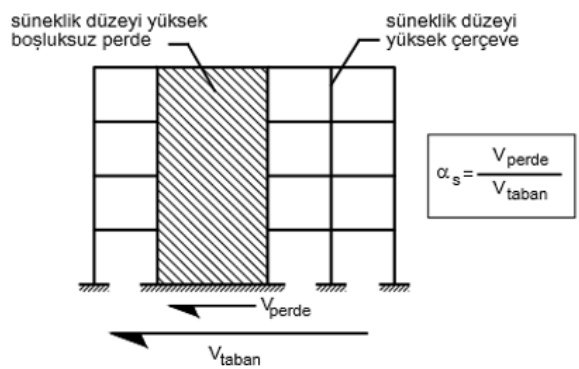

Şekil 2. Perdenin ve binanın taban kesme kuvveti (Darılmaz, 2012)

\section{Yapı Modellerinin Analizi}

$\mathrm{Bu}$ çalışmada, taşıyıcı elemanların değişkenlik gösterdiği 10 farklı yapısal model bir sonlu elemanlar programı kullanılarak üretilmiş olup çıkan sonuçlar yerdeğiştirme, titreşim periyodları, kesme kuvvetleri, perde katkı katsayısı ve taşıyıcı sistem katsayıları açısından değerlendirilmiştir (Kaya, 2018). “Eşdeğer Deprem Yükü Yöntemi”ne göre hesaplanan yatay deprem yükleri $\pm 0,05$ dış merkezlik göz önünde bulundurularak, kat düzlemlerine uygulanmıştır (Özmen, vd., 2013). Her yapı modeli için 4 farklı deprem yüklemesi uygulanmış; planda simetrik olan yapı modelleri için deprem yüklerinin $-0,05$ veya $+0,05$ dış merkezli olarak uygulanması sonucu değiștirmemektedir. Perdelerin sonlu elemanlar modelinde kabuk eleman (shell) kullanılmış ve kat düzlemleri için rijit diyafram kabulü yapılmıştır. Sayısal modellere ve deprem hesabına ait bilgiler Tablo (1)'de verilmiștir.

Tablo 1. Yapısal Modelleme ve Deprem Hesabı

\begin{tabular}{|l|c|}
\hline \multicolumn{2}{|c|}{ Sayısal Model Bilgileri } \\
\hline Kolon Boyutları & $0,55 \mathrm{~m} \mathrm{x} \mathrm{0,55}$ \\
\hline Kiriş Boyutları & $0,50 \mathrm{~m} \mathrm{x} \mathrm{0,25}$ \\
\hline Kat Yüksekliği & $3 \mathrm{~m}$ \\
\hline Perde Kalınlığı & $0,25 \mathrm{~m}$ \\
\hline Kat Adedi & 7 \\
\hline Yapı Yüksekliği & $21 \mathrm{~m}$ \\
\hline Kat Alanı & $400 \mathrm{~m}^{2}$ \\
\hline X ve Y Açıklık Mesafeleri & $5 \mathrm{~m}-4 \mathrm{~m}$ \\
\hline X ve Y Açıklık Sayısı & $5-4$ \\
\hline Kat Ağırlı̆̆ı & $4774,06 \mathrm{kN}$ \\
\hline Bina Ağırlı̆̆ı & $31974,58 \mathrm{kN}$ \\
\hline Bina Önem Katsayısı & 1 \\
\hline Beton Sınıfı & $\mathrm{C} 25$ \\
\hline Poisson Oranı & 0,2 \\
\hline Elastisite Modülü & $30000 \mathrm{MPa}$ \\
\hline \multicolumn{2}{|c|}{ Deprem Hesap Değerleri } \\
\hline Deprem Bölgesi & 1. Bölge \\
\hline Etkin Yer İvmesi Katsayısı (A $)$ & 0,4 \\
\hline Yerel Zemin Sınıfı & Z2 \\
\hline Hareketli Yük Katılım Sayısı (n) & 0,3 \\
\hline \multicolumn{2}{|c|}{} \\
\hline
\end{tabular}

\section{1. Çerçeve Modeli ve Perde-Çerçeve Modeli}

Şekil (3)'te kat planı ve bina modeli gösterilen Örnek 1 , yatay yüklerin tamamen çerçeve ile taşındığ taşıyıcı sistemi $(\mathrm{R}=8)$ temsil etmektedir. Örnek 10'da ise çerçeve sisteme her iki yönde tamamen boşluksuz perdeler ilave edilmiştir. Örnek 10, taşıyıcı sistem davranış katsayısı açısından ( $\mathrm{x}$ ve $\mathrm{y}$ yönü için $R=6.04$ ve $R=6.08$ ) üretilen yapısal modeller arasında en rijit yapıyı temsil etmektedir. $\mathrm{Bu}$ iki uç örnek karşılaştırıldığında perdelerin eklenmesiyle titreşim periyodunun çerçeve sisteme göre düştüğü Tablo (2)'de görülmektedir. Tablo (3)'de, perde-çerçeve sistemin her iki yönde kat kesme kuvvetlerinin çerçeve sisteme göre daha yüksek olduğu görülmektedir.

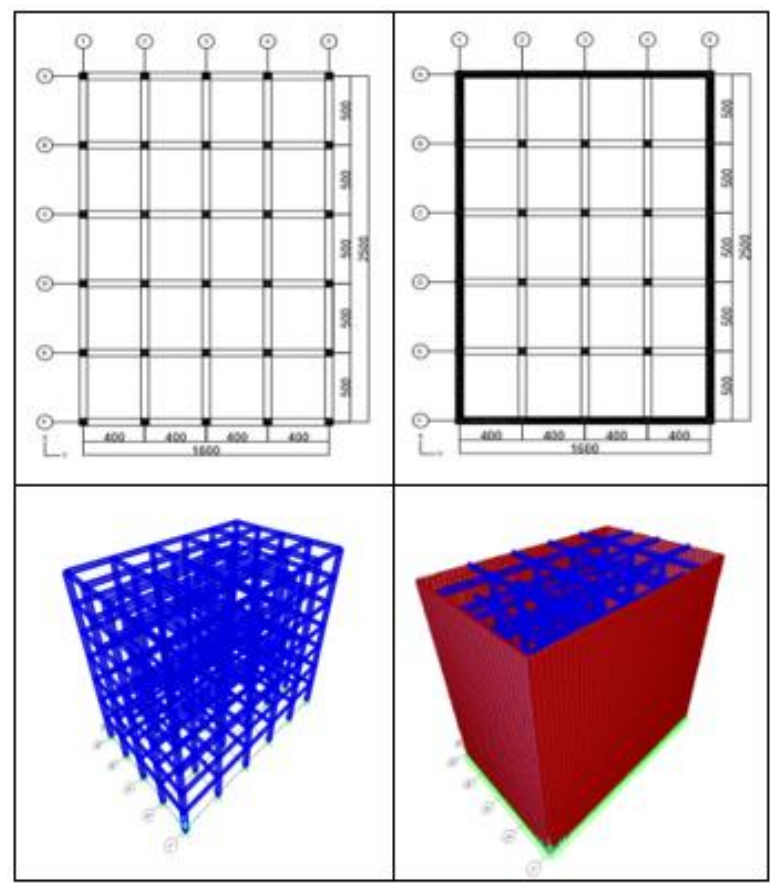

Şekil 3. Örnek 1 ve Örnek 10’un kalıp planı ve bina modeli(Computers and Structures, Inc.)

Tablo 2. Örnek 1 ve Örnek 10’un deprem hesabı

\begin{tabular}{|l|c|c|c|c|}
\hline & \multicolumn{2}{|c|}{ ÖRNEK 1 } & \multicolumn{2}{c|}{ ÖRNEK 10 } \\
\hline & X Yönü & Y Yönü & X Yönü & Y Yönü \\
\hline Periyot (sn) & 0,87204 & 0,82801 & 0,10272 & 0,13690 \\
\hline Spektrum Kats. & 1,340 & 1,397 & 2,027 & 2,369 \\
\hline $\begin{array}{l}\text { Spektral İvme } \\
\text { Kat. }\end{array}$ & 0,536 & 0,559 & 0,8108 & 0,9476 \\
\hline $\begin{array}{l}\text { Taban Kesme } \\
\text { Kuv. (kN) }\end{array}$ & 2142,30 & 2234,22 & 5623,64 & 5334,35 \\
\hline$\alpha_{\text {s Oranı }}$ & - & - & 0,99 & 0,98 \\
\hline R Katsayısı & 8 & 8 & 6,04 & 6,08 \\
\hline
\end{tabular}


Tablo 3 . Örnek 1 ve Örnek 10’un kat kesme kuvvetleri

\begin{tabular}{|c|c|c|c|c|}
\hline & \multicolumn{2}{|c|}{ Örnek 1 } & \multicolumn{2}{c|}{ Örnek 10 } \\
\hline & X Yönü & Y Yönü & X Yönü & Y Yönü \\
\hline Kat No & $\mathrm{V}_{\mathrm{i}}(\mathrm{kN})$ & $\mathrm{V}_{\mathrm{i}}(\mathrm{kN})$ & $\mathrm{V}_{\mathrm{i}}(\mathrm{kN})$ & $\mathrm{V}_{\mathrm{i}}(\mathrm{kN})$ \\
\hline 7 & 495,50 & 516,77 & 1300,71 & 1233,80 \\
\hline 6 & 966,01 & 1007,47 & 2535,83 & 2405,39 \\
\hline 5 & 1358,17 & 1416,46 & 3565,28 & 3381,88 \\
\hline 4 & 1671,78 & 1743,52 & 4388,52 & 4162,77 \\
\hline 3 & 1907,04 & 1988,87 & 5006,08 & 4748,56 \\
\hline 2 & 2063,95 & 2152,51 & 5417,96 & 5139,26 \\
\hline 1 & 2142,30 & 2234,22 & 5623,64 & 5334,35 \\
\hline
\end{tabular}

\subsection{Y-Yönünde Perdelerin Yerleştirildiği Yapısal Modeller}

Şekil (4)'te verilen kat planları esas alınarak modellenen Örnek 2, 3 ve 4'te çerçeve sistemin cephesine Y doğrultusunda perde yerleștirilmiștir. $\mathrm{Bu}$ modellerin sayısal analizinde, $\mathrm{Y}$ doğrultusunda tamamen cephenin perde ile teşkil edildiği sistemi temsil eden Örnek 4'ün titreşim periyodunun $\mathrm{T}_{Y}$ =0.184' e kadar düştüğü; aynı boyutlarda perdeye sahip Örnek 2 ve Örnek 3'ün perde konumlarının farklı olmasıyla birlikte periyot değerlerinin farklılık gösterdiği gözlemlenmiştir (Tablo 4). Perdenin konulduğu $\quad Y$ doğrultusunda $\alpha$ s katsayısı 0,75 değerinden büyük olduğu için Tașıyıcı Sistem Davranıș Katsayısı'nın 7'nin altına düșmüștür. Bu da örneklerin Y doğrultularındaki taban kesme kuvvetlerini ve kat kesme kuvvetlerini arttırmıștır (Tablo 5).

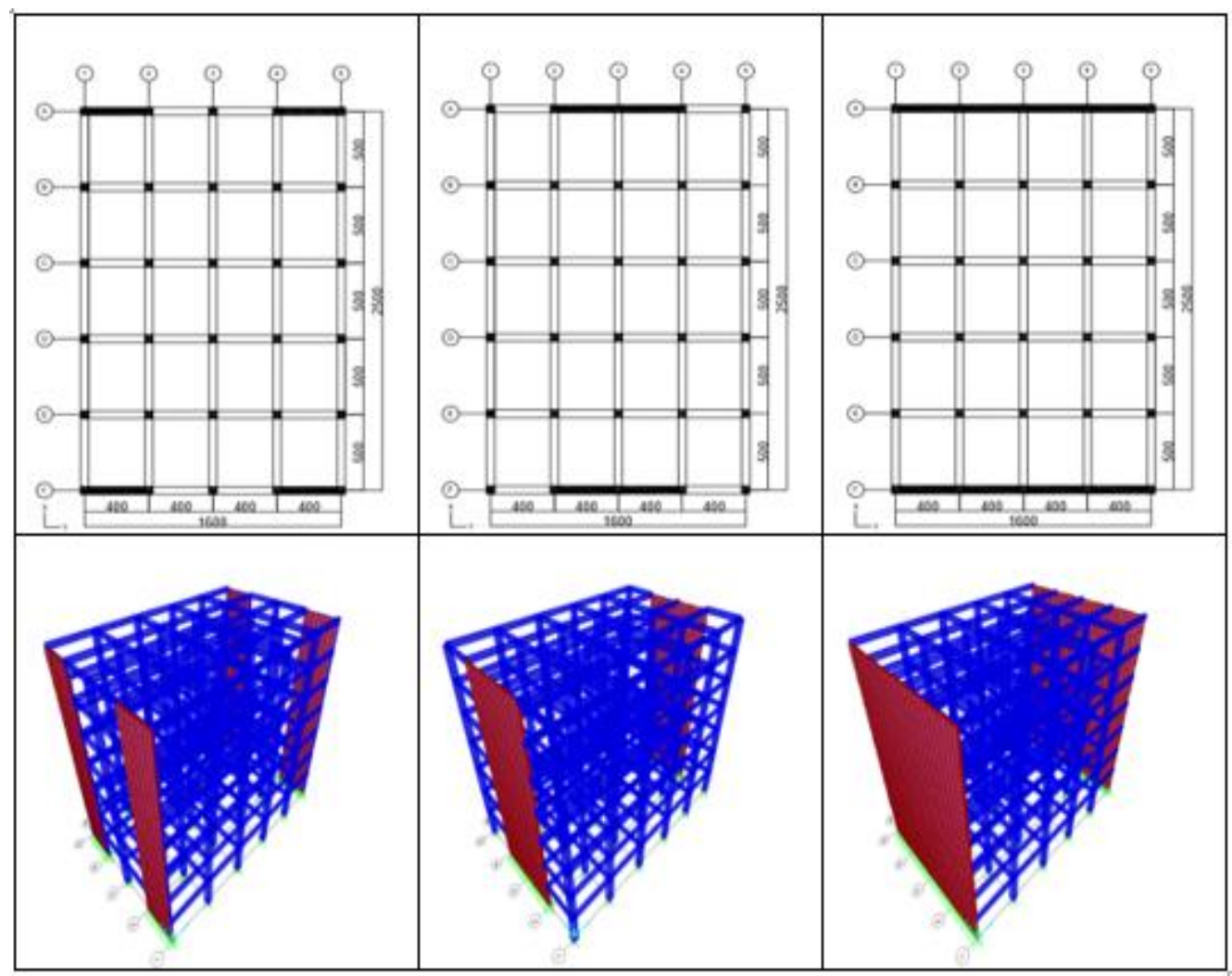

Şekil 4. Örnek 2, Örnek 3 ve Örnek 4'ün kalıp planı ve bina modeli(Computers and Structures, Inc.)

Tablo 4. Örnek 2, Örnek 3 ve Örnek 4'ün deprem hesabı

\begin{tabular}{|l|c|c|c|c|c|c|}
\hline & \multicolumn{2}{|c|}{ ÖRNEK 2 } & \multicolumn{2}{c|}{ ÖRNEK 3 } & \multicolumn{2}{c|}{ ÖRNEK 4 } \\
\hline & X Yönü & Y Yönü & X Yönü & Y Yönü & X Yönü & Y Yönü \\
\hline Periyot (sn) & 0,92918 & 0,57040 & 0,90608 & 0,38126 & 0,92254 & 0,18411 \\
\hline Spektrum Katsayısı & 1,273 & 1,882 & 1,300 & 2,5 & 1,281 & 2,5 \\
\hline Spektral İvme Katsayısı & 0,5092 & 0,7528 & 0,5200 & 1 & 0,5124 & 1 \\
\hline Taban Kesme Kuvveti $(\mathrm{kN})$ & 2325,92 & 3603,36 & 2375,25 & 4965,00 & 2340,54 & 5224,60 \\
\hline$\alpha_{\text {s Oranı }}$ & 0,11 & 0,83 & 0,10 & 0,89 & 0,20 & 0,97 \\
\hline R Katsayısı & 7 & 6,68 & 7 & 6,44 & 7 & 6,12 \\
\hline
\end{tabular}


Tablo 5. Örnek 2, Örnek 3 ve Örnek 4'ün kat kesme kuvvetleri

\begin{tabular}{|c|c|c|c|c|c|c|}
\hline & \multicolumn{2}{|c|}{ Örnek 2 } & \multicolumn{2}{c|}{ Örnek 3 } & \multicolumn{2}{c|}{ Örnek 4 } \\
\hline & X Yönü & Y Yönü & X Yönü & Y Yönü & X Yönü & Y Yönü \\
\hline Kat No & $\mathrm{V}_{\mathrm{i}}(\mathrm{kN})$ & $\mathrm{V}_{\mathrm{i}}(\mathrm{kN})$ & $\mathrm{V}_{\mathrm{i}}(\mathrm{kN})$ & $\mathrm{V}_{\mathrm{i}}(\mathrm{kN})$ & $\mathrm{V}_{\mathrm{i}}(\mathrm{kN})$ & $\mathrm{V}_{\mathrm{i}}(\mathrm{kN})$ \\
\hline 7 & 537,97 & 833,43 & 549,38 & 1148,37 & 541,35 & 1208,42 \\
\hline 6 & 1048,81 & 1624,84 & 1071,06 & 2238,84 & 1055,40 & 2355,90 \\
\hline 5 & 1474,59 & 2284,46 & 1505,86 & 3147,72 & 1483,85 & 3312,30 \\
\hline 4 & 1815,08 & 2811,95 & 1853,57 & 3874,54 & 1826,48 & 4077,12 \\
\hline 3 & 2070,50 & 3207,65 & 2114,41 & 4419,77 & 2083,51 & 4650,86 \\
\hline 2 & 2240,85 & 3471,57 & 2288,38 & 4783,41 & 2254,94 & 5033,52 \\
\hline 1 & 2325,92 & 3603,36 & 2375,25 & 4965,00 & 2340,54 & 5224,60 \\
\hline
\end{tabular}

\subsection{X-Yönünde Perdelerin Yerleştirildiği Yapısal Modeller}

Örnek 5, 6 ve 7 çerçeve sisteme X doğrultusunda perde yerleştirilerek oluşturulan yapısal modellerdir (Şekil 5). Bu modellerin sayısal analizi ve deprem hesabına ait sonuçlar Tablo (6)'te özetlenmiştir. $\mathrm{X}$ doğrultusunda tamamen cephenin perde ile teşkil edildiği sistemi temsil eden Örnek 7'nin titreşim periyodunun $\mathrm{T}_{\mathrm{X}}=0,1196$ 'ya kadar düştüğü; aynı boyutlarda ayrık konumlandırılmış perdeye sahip Örnek 5 ve Örnek 6'nın perde konumlarının farklı olması periyot değerlerini etkilememiştir. Perdenin konulduğu X doğrultusunda $\alpha_{s}$ katsayısı 0,75 değerini geçerek Taşıyıcı Sistem Davranış Katsayısı'nın 7'den küçük bir değer almasına neden olmuştur. Bu da örneklerin $\mathrm{X}$ doğrultularındaki taban kesme kuvvetlerini arttırmıştır (Tablo 7).

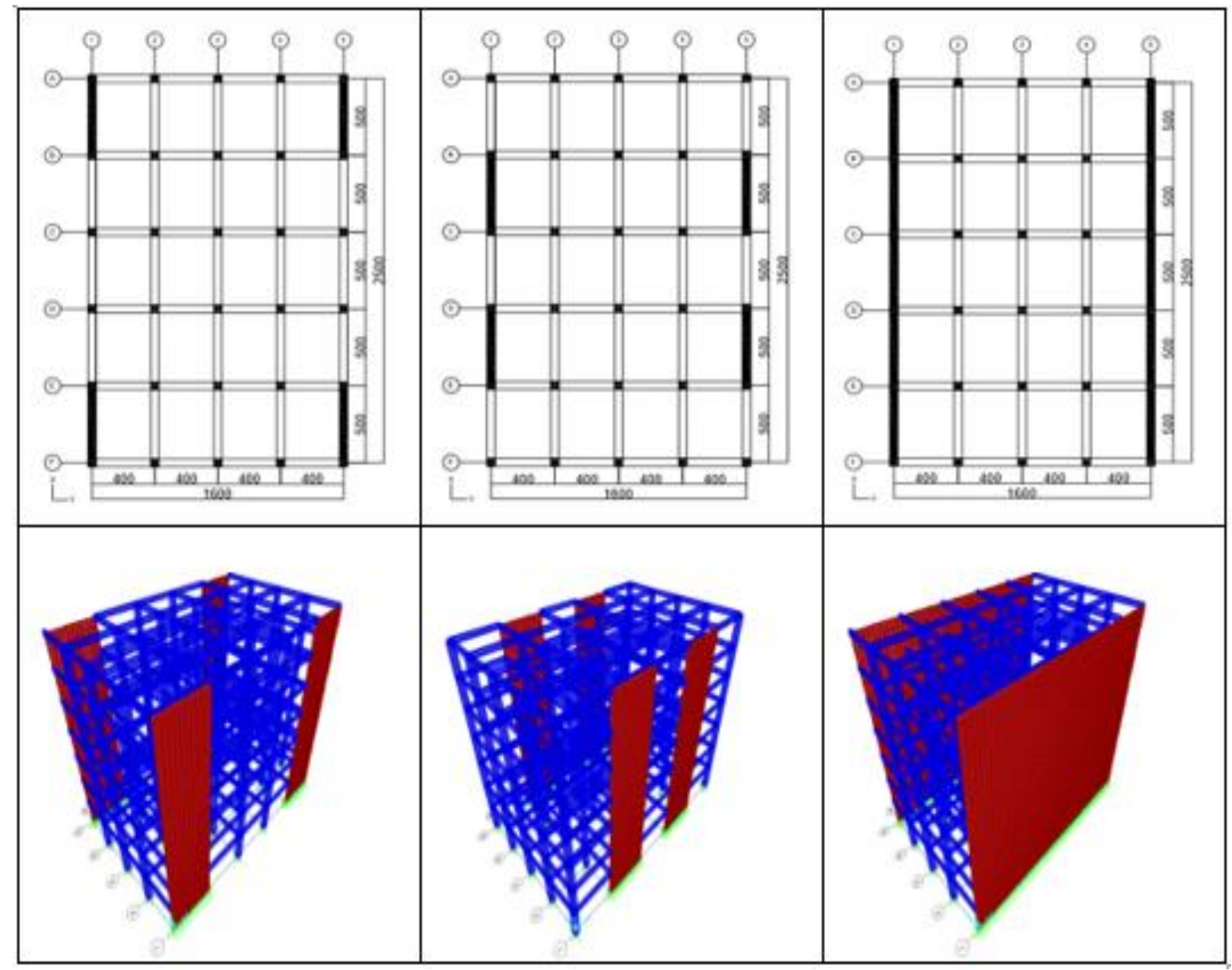

Şekil 5. Örnek 5, Örnek 6 ve Örnek 7'nin kalıp planı ve bina modeli (Computers and Structures, Inc.) 
Tablo 6. Örnek 5, Örnek 6 ve Örnek 7'nin deprem hesabı

\begin{tabular}{|l|c|c|c|c|c|c|}
\hline & \multicolumn{2}{|c|}{ ÖRNEK 5 } & \multicolumn{2}{c|}{ ÖRNEK 6 } & \multicolumn{2}{c|}{ ÖRNEK 7 } \\
\hline & X Yönü & Y Yönü & X Yönü & Y Yönü & X Yönü & Y Yönü \\
\hline Periyot (sn) & 0,48344 & 0,88496 & 0,48528 & 0,88496 & 0,11964 & 0,88309 \\
\hline Spektrum Katsayısı & 2,148 & 1,324 & 2,142 & 1,324 & 2,196 & 1,327 \\
\hline Spektral İvme Katsayısı & 0,8592 & 0,5296 & 0,8568 & 0,5296 & 0,8784 & 0,5308 \\
\hline Taban Kesme Kuvveti $(\mathrm{kN})$ & 4239,59 & 2419,11 & 4227,75 & 2419,11 & 5453,68 & 2424,59 \\
\hline$\alpha_{s}$ Oranı & 0,88 & 0,12 & 0,88 & 0,12 & 0,98 & 0,27 \\
\hline R Katsayısı & 6,48 & 7 & 6,48 & 7 & 6,08 & 7 \\
\hline
\end{tabular}

Tablo 7. Örnek 5, Örnek 6 ve Örnek 7'nin kat kesme kuvvetleri

\begin{tabular}{|c|c|c|c|c|c|c|}
\hline & \multicolumn{2}{|c|}{ Örnek 5 } & \multicolumn{2}{c|}{ Örnek 6 } & \multicolumn{2}{c|}{ Örnek 7 } \\
\hline & X Yönü & Y Yönü & X Yönü & Y Yönü & X Yönü & Y Yönü \\
\hline Kat No & $\mathrm{V}_{\mathrm{i}}(\mathrm{kN})$ & $\mathrm{V}_{\mathrm{i}}(\mathrm{kN})$ & $\mathrm{V}_{\mathrm{i}}(\mathrm{kN})$ & $\mathrm{V}_{\mathrm{i}}(\mathrm{kN})$ & $\mathrm{V}_{\mathrm{i}}(\mathrm{kN})$ & $\mathrm{V}_{\mathrm{i}}(\mathrm{kN})$ \\
\hline 7 & 980,59 & 559,52 & 977,85 & 559,52 & 1261,40 & 560,79 \\
\hline 6 & 1911,73 & 1090,83 & 1906,39 & 1090,83 & 2459,19 & 1093,30 \\
\hline 5 & 2687,82 & 1533,67 & 2680,31 & 1533,67 & 3457,52 & 1537,14 \\
\hline 4 & 3308,45 & 1887,80 & 3299,21 & 1887,80 & 4255,88 & 1892,07 \\
\hline 3 & 3774,02 & 2153,46 & 3763,48 & 2153,46 & 4854,78 & 2158,33 \\
\hline 2 & 4084,53 & 2330,64 & 4073,13 & 2330,64 & 5254,22 & 2335,91 \\
\hline 1 & 4239,59 & 2419,11 & 4227,75 & 2419,11 & 5453,68 & 2424,59 \\
\hline
\end{tabular}

\section{4. $X$ ve $Y$ Yönünde Perdelerin Yerleştirildiği Yapısal Modeller}

Şekil (6)'da verilen Örnek 8 ve 9, çerçeve sisteme X ve $Y$ doğrultusunda perde yerleştirilerek oluşturulan yapısal modellerdir. Projelendirme öncesi taşıyıcı sistemin bu iki modelde olduğu gibi perde yerlerinin her iki doğrultuda simetrik bir şekilde yerleştirilmesi önerilmektedir (Celep, 2013).

Örnek 8 ve Örnek 9'da yapının her iki doğrultusuna da eşit boyutlarda ve farklı konumlarda perde yerleştirilmiş olup $\alpha_{s}$ katsayısı her iki doğrultuda sınır değeri aşarak Taş̧ıyıcı Sistem Davranış Katsayısı'nın tekrar hesaplanmasina neden olmuştur.

Tablo (8)'de verilen sonuçlar incelendiğinde, her iki sistemin R değerlerinin birbirine çok yakın olduğu görülmektedir. Planda köşelerde perdelerin bulunduğu sistemde (Örnek 8), X yönü taban kesme kuvvetinin ve kat kesme kuvvetlerinin $Y$ yönündeki değerlere göre daha yüksek olduğu gözlemlenmektedir (Tablo 9).

Tablo 8. Örnek 8 ve Örnek 9'un deprem hesabı

\begin{tabular}{|l|c|c|c|c|}
\hline & \multicolumn{2}{|c|}{ ÖRNEK 8 } & \multicolumn{2}{c|}{ ÖRNEK 9 } \\
\hline & X Yönü & Y Yönü & X Yönü & Y Yönü \\
\hline Periyot (sn) & 0,37899 & 0,45270 & 0,49283 & 0,38792 \\
\hline Spektrum Kats. & 2,5 & 2,264 & 2,116 & 2,5 \\
\hline Spektral İvme Kat. & 1 & 0,9056 & 0,8464 & 1 \\
\hline Taban Kesme Kuv.(kN) & 5059,27 & 4496,30 & 4255,23 & 5059,27 \\
\hline$\alpha_{s}$ Oranı & 0,92 & 0,89 & 0,91 & 0,92 \\
\hline R Katsayısı & 6,32 & 6,44 & 6,36 & 6,32 \\
\hline
\end{tabular}

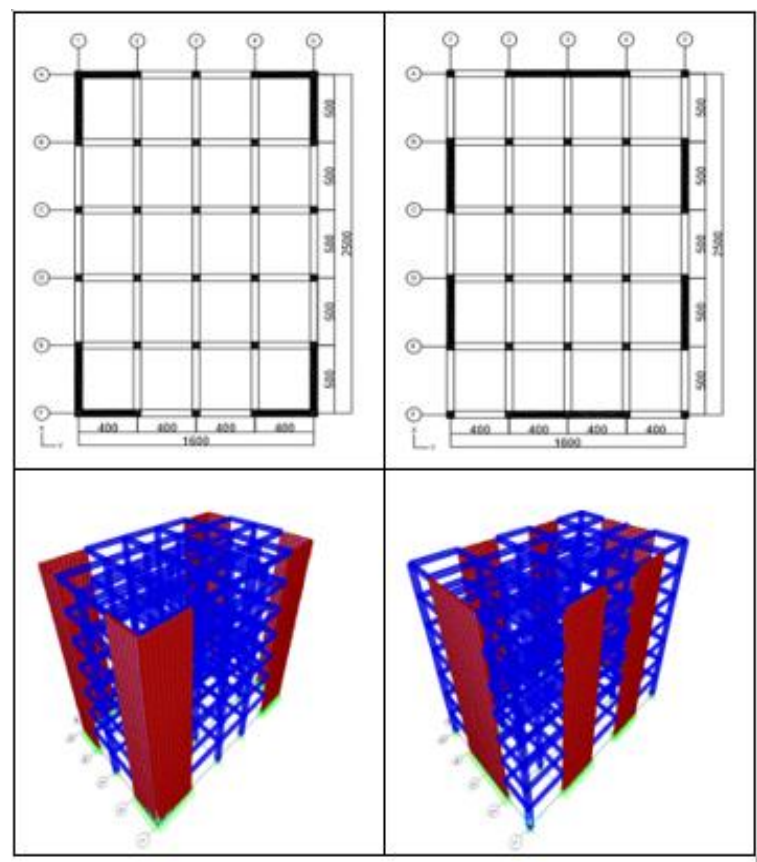

Şekil 6. Örnek 8 ve Örnek 9'un kalıp planı ve bina modeli 
Tablo 9. Örnek 8 ve Örnek 9'un kat kesme kuvvetleri

\begin{tabular}{|c|c|c|c|c|}
\hline & \multicolumn{2}{|c|}{ Örnek 8 } & \multicolumn{2}{c|}{ Örnek 9 } \\
\hline & X Yönü & Y Yönü & X Yönü & Y Yönü \\
\hline Kat No & $\mathrm{V}_{\mathrm{i}}(\mathrm{kN})$ & $\mathrm{V}_{\mathrm{i}}(\mathrm{kN})$ & $\mathrm{V}_{\mathrm{i}}(\mathrm{kN})$ & $\mathrm{V}_{\mathrm{i}}(\mathrm{kN})$ \\
\hline 7 & 1170,17 & 1039,97 & 984,20 & 1170,17 \\
\hline 6 & 2281,34 & 2027,49 & 1918,78 & 2281,34 \\
\hline 5 & 3207,48 & 2850,57 & 2697,73 & 3207,48 \\
\hline 4 & 3748,10 & 3508,78 & 3320,65 & 3948,10 \\
\hline 3 & 4503,68 & 4002,54 & 3787,94 & 4503,68 \\
\hline 2 & 4874,23 & 4331,86 & 4099,60 & 4874,23 \\
\hline 1 & 5059,27 & 4496,30 & 4255,23 & 5059,27 \\
\hline
\end{tabular}

\section{Sonuçların Karşılaştırılması}

Bu bölümde, betonarme çerçeveli yapılarda plandaki boyutu ve konumu farklı perdelerin yerleștirilmesinin yapıların yapısal davranıșına olan etkisini araştırmak üzere oluşturulan üç boyutlu modellerin analiz sonuçları karşılaștırılmıştır.

\subsection{Periyot Değerleri}

Modellerin X ve Y doğrultularına konumu ve boyutu farklı olan simetrik perdeler yerleștirilmiștir. $\mathrm{Bu}$ perdelerin katkısıyla yapı modal analiz sonucunda ilk meydana gelecek farklılık sistemin periyotlarıdır. Tablo (10)'da görüldüğü gibi perde boyutları fazla olan sistemlerin periyotlarının, perde boyutları az olan sistemlere karşın periyotlarının daha düşük olduğu, tek doğrultuda konumlandırılan perdelerin, perde konulmayan doğrultudaki periyodu arttırdığı, perdenin her iki doğrultuda konumlandırılması durumunda ise iki doğrultuda da periyodun düștüğü görülmüștür. Perdelerin birbiriyle bitișik olarak konumlandırılmasının ayrı olarak planda konumlandırılmasına göre periyodunu daha fazla düşürdüğü ve bulunduğu doğrultunun rijitliğini arttırdığı gözlemlenmiștir.

Daha önceki çalışmalar ile uyumlu olarak (Iş̧k vd 2017; Uçar vd. 2014; Gürbüz vd. 2013) çerçeve sisteme (Örnek 1) ilave edilen perdeler kendi doğrultularında yapıyı rijitleştirmiş; yapısal periyotta düşüş̧e sebep olmuştur. Tek doğrultuda ilave edilen perdeler X ve Y yönü periyotlar arasında 2 ila 8 kat farklılığa sebep olmuş; yatay yükler altında yapı rijitlik değerlerinde dengesizlik meydana getirmiștir.
Tablo 10. Periyot değerlerinin karșılaștırılması

\begin{tabular}{|c|c|c|c|c|c|}
\hline Örnek No & Örnek-1 & Örnek-2 & Örnek-3 & Örnek-4 & Örnek-5 \\
\hline & & 13 & 1 & & E] \\
\hline $\mathrm{T}_{1 \mathrm{X}}(\mathrm{sn})$ & 0,87204 & 0,92918 & 0,90608 & 0,92254 & 0,48344 \\
\hline $\mathrm{T}_{1 \mathrm{Y}}(\mathrm{sn})$ & 0,82801 & 0,57040 & 0,38126 & 0,18411 & 0,88496 \\
\hline Örnek No & Örnek-6 & Örnek-7 & Örnek-8 & Örnek-9 & Örnek-10 \\
\hline $\mathrm{T}_{1 \mathrm{x}}(\mathrm{sn})$ & 0,48528 & 0,11964 & 0,37899 & 0,49283 & 0,10272 \\
\hline $\mathrm{T}_{1 \mathrm{Y}}(\mathrm{sn})$ & 0,88496 & 0,88309 & 0,45270 & 0,38792 & 0,13690 \\
\hline
\end{tabular}

\subsection{Taban Kesme Kuvvetleri}

Şekil (7)'de sistemlerin X ve Y doğrultusuna ait taban kesme kuvvetleri ve çerçeve sisteme göre taban kesme kuvvetlerinin yüzdesel artışı verilmiştir. Taban kesme kuvvetinin yapı ağırlı̆ı ve spektral ivme katsayısıyla doğru orantılı bir şekilde artacağı tahmin edilen bir sonuçtur. Şekil (7)'de taban kesme kuvvetinin periyot değeri düşük sistemlerde yükseldiği yapının periyot değeri arttıkça taban kesme kuvvetinin de bu doğrultuda azaldığı gözlemlenmiștir.

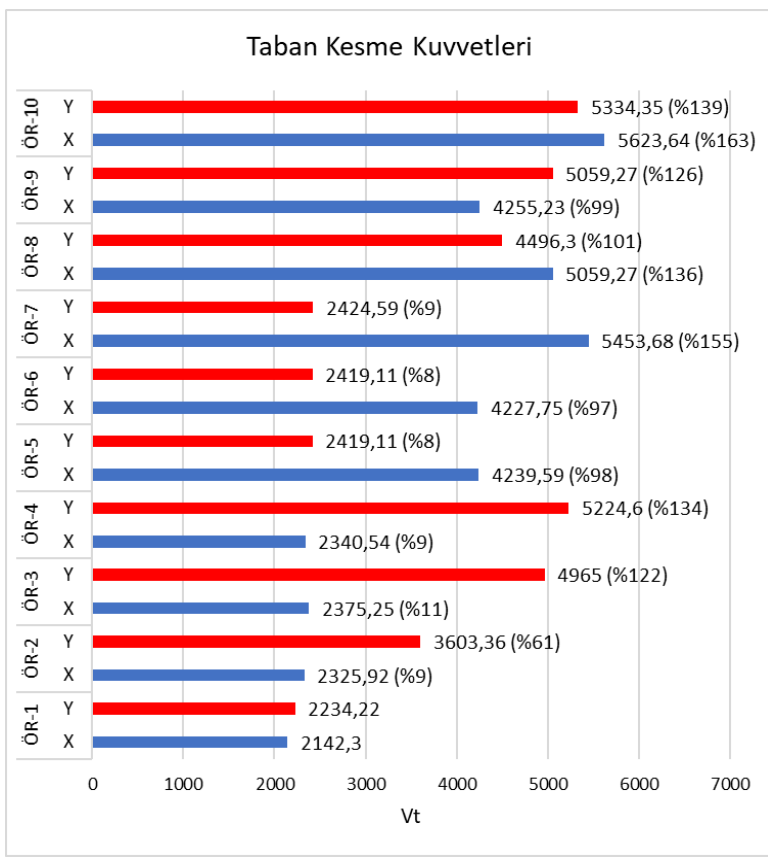

Şekil 7.Taban kesme kuvvetlerinin çerçeve sisteme göre artış yüzdeleri

\section{3. $a_{\mathrm{s}}$ Katsayısı Değerleri}

Yapının Taşıyıcı sistemindeki perde boyutunun artmasıyla yapı daha rijit bir hal alıp periyodu düşerken, perdelerin tabanında meydana gelen kesme kuvvetleri toplamının sistemin toplam taban 
kesme kuvvetine oranı da artıs gösterir. Bu oran 0,75 değerinden ne kadar yüksek olursa yapının taşıyıcı sistem davranış katsayısı da 6 değerine o kadar yaklaşır, dolayısı ile taban kesme kuvvetinde de artış meydana gelir.

Tablo 11. $\alpha_{s}$ oranları

\begin{tabular}{|c|c|c|c|}
\hline Örnek No & Mod eller & $\begin{array}{c}\mathbf{X} \\
\text { Doğrultusu }\end{array}$ & $\begin{array}{c}\mathbf{Y} \\
\text { Doğrultusu }\end{array}$ \\
\hline Örnek 2 & & 0,11 & 0,83 \\
\hline Örnek 3 & & 0,10 & 0,89 \\
\hline Örnek 4 & & 0,20 & 0,97 \\
\hline Örnek 5 & & 0,88 & 0,12 \\
\hline Örnek 6 & & 0,88 & 0,12 \\
\hline Örnek 7 & & 0,98 & 0,27 \\
\hline Örnek 8 & & 0,92 & 0,89 \\
\hline Örnek 9 & & 0,91 & 0,92 \\
\hline Örnek 10 & & 0,99 & 0,98 \\
\hline
\end{tabular}

Tablo (11)'da görüldüğü üzere çevresinin tümüne perde yerleştirilen Örnek 10'un $\alpha_{s}$ katsayısı her iki doğrultuda da 1'e yakın bir değer almıştır. Burada Taşıyıcı sistem davranış katsayısı $R=6$ 'ya yakın bir değer alarak perde gibi davranış sergilemiştir. Tek doğrultusunda perde bulunan modellerde ise perde bulunan doğrultuda $\mathrm{R}=6$ değerine yaklaşırken perde bulunmayan doğrultuda $\mathrm{R}=7$ olarak kalmıştır.

\subsection{Kat Yerdeğiștirmeleri}

Şekil (8) ve Şekil (9)'da görüldüğü üzere yatay rijitliği yüksek olan sistemlerin daha az yer değiştirme yaptığı görülmektedir. Kat yüksekliği ile birlikte yer değiștirme miktarında da artış olduğu gözlemlenmiştir. Yalnız X doğrultusunda perde bulunan Örnek 7'de, bu doğrultuda yer değiștirme maksimum $0,12 \mathrm{~cm}$ iken perde bulunmayan diğer doğrultuda yer değiștirme değerinin 2,5 cm'ye kadar çıktı̆̆ı görülmektedir.

\subsection{Göreli Kat Ötelemeleri}

Şekil 10. ve Şekil 11.'de yapısal modellerin yatay yükler altında analizi sonucunda elde edilen etkin göreli kat ötelemeleri oranları görülmektedir. Şekil 10.'da görüldüğg̈ gibi $X$ doğrultusunda perde bulunmayan modellerde 3 . kattan sonra etkin göreli kat ötelemesi azalış gösterirken X doğrultusunda perde bulunan sistemlerde üst katlara doğru etkin göreli kat ötelemesi yükseliş göstermiștir. $\mathrm{X}$ doğrultusunda çevresinin tümüne perde yerleștirilmiş sistemlerin ise göreli kat ötelemeleri diğer sistemlere göre sınırlı düzeyde kalmıștır.

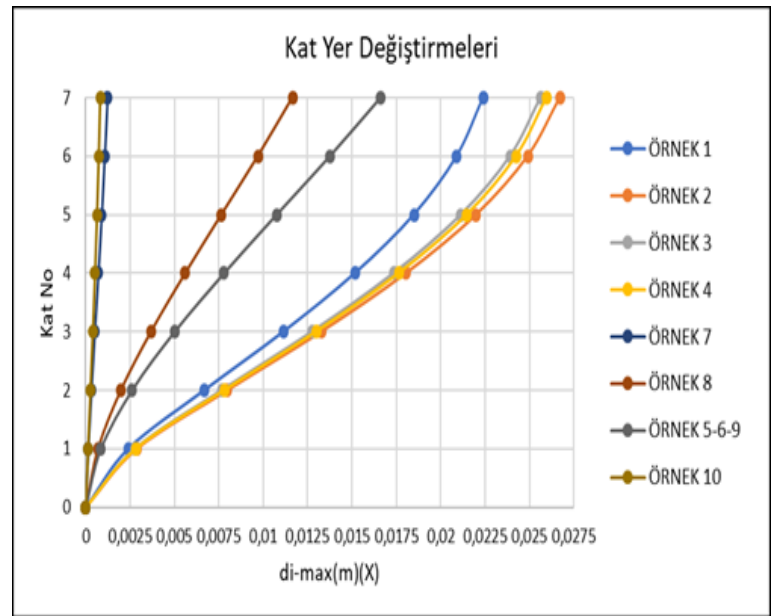

Şekil 8. X doğrultusundaki maksimum kat yerdeğiştirmeleri

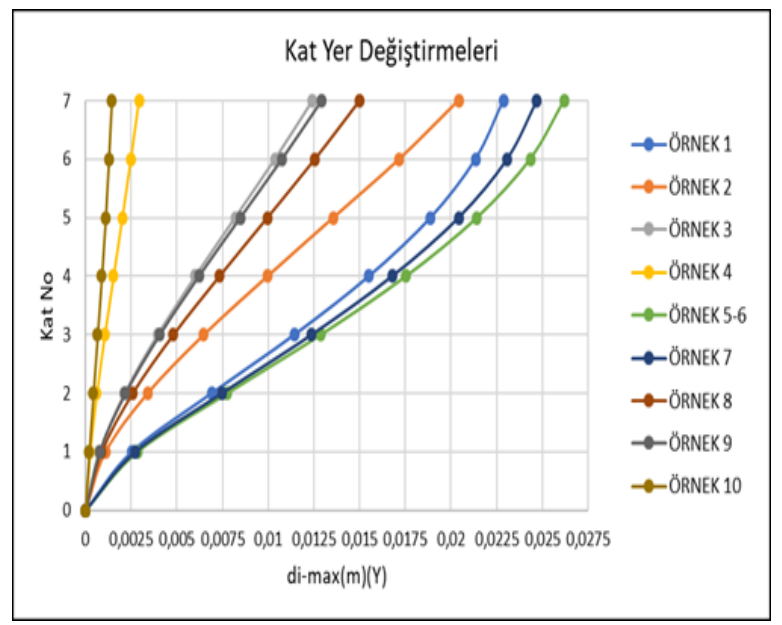

Şekil 9. Y doğrultusundaki maksimum kat yerdeğiştirmeleri

Şekil (11)'de Y doğrultusundaki etkin göreli kat ötelemelerine bakıldığında ise perde bulunmayan modellerde 2 ve 3 . katta maksimuma çıkan etkin göreli kat ötelemeleri 3. kattan sonra düşüş göstermeye başlamıştır. Y doğrultusunda perde bulunan modellerde ise alt katlarda çerçeve sisteme göre daha az kat ötelemesi yaparken 6 ve 7. katlarda çerçeve sisteme göre fazla göreli kat ötelemesi yaptığı görülmüştür. Y doğrultusunda çevresinin tamamına perde yerleștirilmiș sistemlerde ise göreli kat ötelemeleri sınırlı düzeyde kalmıştır.

Elde edilen sonuçlar doğrultusunda çerçevelerin daha çok üst katlarda perdelerin ise daha çok alt katlarda etkin olup ötelenmeleri karşıladıkları sonucuna varılabilir. Perdelerin daha etkin olduğu yapı sistemlerinde yapısal davranış düşey bir konsol kirișe benzerken, çerçeve sistemde göreli kat öteleme oranları alt katlarda daha büyük değerlere ulaşmaktadır. 
Bütün katlarda $\left(\delta_{\mathrm{i}}\right)_{\max } / \mathrm{h}_{\mathrm{i}} \leq 0,02$ koşulu sağlandığından dolayı göreli kat ötelemeleri oranı yönetmelikteki sınır değerin altındadır.

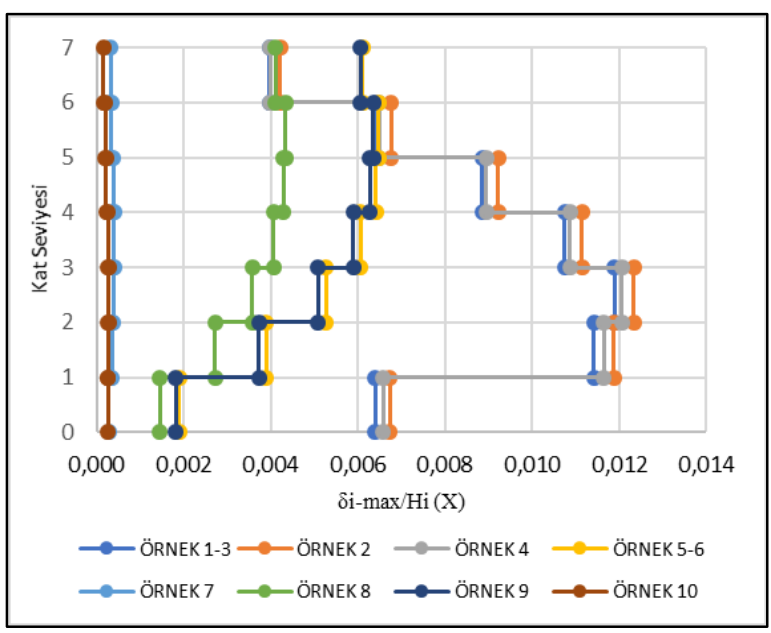

Şekil 10. X doğrultusundaki maksimum etkin göreli kat ötelemeleri

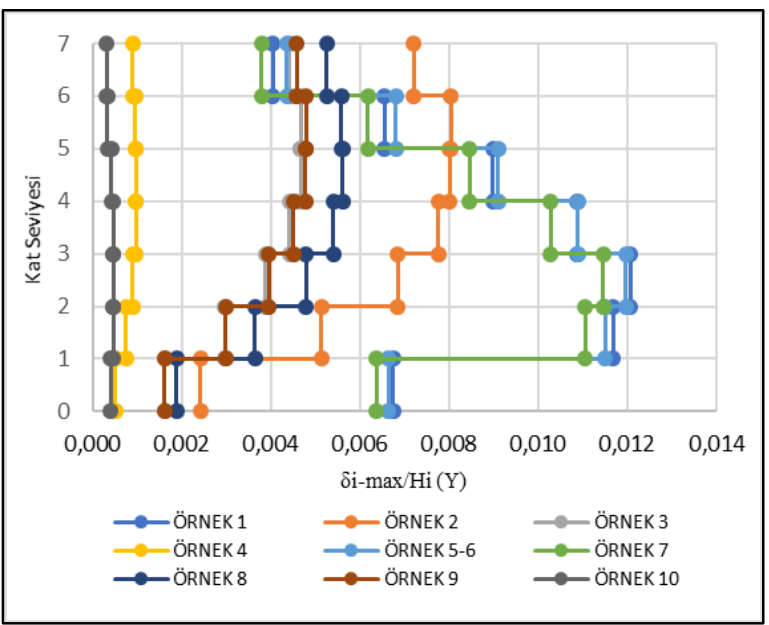

Şekil 11. Y doğrultusundaki maksimum etkin göreli kat ötelemeleri

\section{Sonuçlar}

Deprem etkisi altında betonarme yapıların tasarımında yatay yükleri karşılayan düşey taşıyıcı elemanların boyutlandırılması yapı güvenliği ve maliyeti açısından önem tașımaktadır. Kat adedinin artması ile betonarme binalarda moment aktaran çerçeve sistem, yatay rijitliğin sağlanmasında yeterli olmayabilir. Deprem yüklerinin çerçeve ve perdeler ile taşındığı betonarme yapılarda perdeler kesit alanları ve yüksek eğilme rijitlikleri ile yatay yükün önemli kısmını karşılar; yatay ötelemeleri ve ikinci mertebe etkilerini sinırlandırır. Ancak, perdenin plandaki boyutu ve yerleșimi yapı üzerindeki yük akıșını etkiler. $\mathrm{Bu}$ sebeple, perde ve çerçeveli yapılarda düşey taşıyıcı elemanların düzenlenmesi yapı güvenliğini ve maliyetini etkileyen bir ön tasarım problemidir.
Bu çalıșmada, deprem yüklerinin çerçeve ve perdeler ile taşındığ konumu ve boyutlarının yapısal davranışa etkisi araştırılmıştır. Plan boyutları ve açıklıkları aynı olan 7 katlı 10 farklı yapı modeli bir sonlu elemanlar analiz programı ile geliştirilmiştir. Yapı modellerinde planda $\mathrm{X}$ ve $\mathrm{Y}$ yönlerine ya da aynı anda $\mathrm{X}$ ve $\mathrm{Y}$ yönüne farklı konumda perde elemanlar yerleștirilmiştir. Daha önceki çalışmalardan farklı olarak bu çalışmada perde ve çerçeve sistemde taşıyıcı sistem davranış katsayısının dinamik davranışa olan etkisi detaylı olarak araștırılmıştır. Her model için taban kesme kuvveti hesabında kullanılan tașıyıcı sistem davranıș katsayısı R; perde katkı oranı katsayısı $\alpha$ s'e bağlı olarak hesaplanmıștır. Tüm yapısal analizlerde tașıyıcı sistem düzenlemesinin doğal titreşim periyodu, kat kesme kuvvetleri ve göreli kat ötelemeleri üzerindeki etkisi değerlendirilmiştir.

$\mathrm{Bu}$ çalışma sonucunda, prototip yapı modellerinin sayısal analizlerinde daha önceki çalışmalarla da belirtilen sonuçlar ile benzer olarak (Ișık vd 2017; Uçar vd. 2014; Gürbüz vd. 2013);

- X ya da Y yönünde sisteme ilave edilen perde elemanlar, yapı sisteminin yatay rijitliğinde artışa ve incelenen doğrultuda titreşim periyodunda düşüşe sebep olmuştur.

- Çerçeve sisteme ilave edilen perde elemanlar, yerleştirilen yönde yapıyı rijitleştirirken aynı zamanda yapıya etkiyen taban kesme kuvvetini de arttırmaktadır.

- Çerçeve sisteme ait yapı modelinde etkin göreli kat öteleme değeri üst katlarda azalırken perdeli sistemlerde üst katlarda artmaktadır.

Perde alanı artışı ile toplam deprem yükünün büyük bir bölümü perde tarafından taşınmakta, perde katkı katsayısı $\alpha$ s, 0,75 değerini aștığı için tașıyıcı sistem davranış katsayısı da 6'ya yaklaşmaktadır.

Yapılarda deprem güvenliğinin sağlanması için her iki yönde perde elemanların yerleştirilmesi, yapının asal eksenleri doğrultusunda birbirine yakın titreşim periyodlarına sahip olmasını sağlar. Perde elemanlarının kesme alanları ile birlikte plandaki yerleșiminin de yapı davranışında önemli rol oynadığı göz ardı edilmemelidir.

\section{Conflict of Interest / Çıkar Çatışması}

Yazarlar tarafından herhangi bir çıkar çatışması beyan edilmemiştir.

No conflict of interest was declared by the authors.

\section{Kaynaklar}

Afet Bölgelerinde Yapılacak Yapılar Hakkında Yönetmelik (ABYYHY) (1998). Bayındırlık ve İskan Bakanlığı, Ankara. 
Aka, İ., Keskinel, F., Çıll, F., \& Çelik, O. C. (2001). Betonarme. İstanbul: Birsen Yayınevi.

Aktan, S., Kıraç, N., 2010, Betonarme Binalarda Perdelerin Davranışa Etkileri, Eskişehir Osmangazi Üniversitesi Mühendislik Mimarlık Fakültesi Dergisi 23(1), 15-32.

Celep, Z. (2013). Betonarme Yapılar. İstanbul: Beta Dağıtım.

Darılmaz, K. (2012). Depreme Dayanıklı Betonarme Binaların Tasarımına Giriș. İstanbul: Yapı Yazılım Yayınları.

Deprem Bölgelerinde Yapılacak Binalar Hakkında Yönetmelik (DBYBHY) (2007). Bayındırlık ve İskan Bakanlığı, Ankara.

Doğangün, A. (2016). Betonarme Yapıların Hesap ve Tasarımı. İstanbul: Birsen Yayınevi.

Ersoy U., 2013, Depreme Dayanıklı Betonarme Binaların Öntasarımı İçin Basit Bir Yöntem, İMO Teknik Dergi, 6559-6574, Yazı 409.

Gülay F.G., Özmen G., Doğan F., 1999, Perde Çerçeveli Yapılarda Perde Katkı Katsayısının Hesabı İle İlgili Parametrik İnceleme, Türkiye İnşaat Mühendisliği 15. Teknik Kongresi, Sayfa 417434.

Gürbüz A., Tekin M., Mevcut Betonarme Bir Yapının Perde Duvarlar Kullanarak Deplasmana Dayalı Yöntemle Güçlendirilmesi, 2. Türkiye Deprem Mühendisliği ve Sismoloji Konferansı 25-27 Eylül 2013, Hatay.

Işık E., Yamaç Ö., Erçek M.S., Yamaç İ., 2017, Farklı Taşıyıcı Sistemlerdeki Yaplarda Malzeme Dayanımın Yapı Performansına Etkisi, Erciyes Üniversitesi Fen Bilimleri Enstitüsü Dergisi, Cilt 33, Sayı 1, 33-40.

Kaya, G. (2018). Betonarme Perde ve Çerçeveli Yapılarda Perde Boyutlandırması ve Yerleşiminin Deprem Davranışına Etkisi. İstanbul: Beykent Üniversitesi, Fen Bilimleri Enstitüsü.

Koç Y., Gültekin A.B., Durmuş G., Dikmen Ç.B., Yüksek Yapı Tasarımının Malzeme ve Taşıyıcı Sistem Kapsamında İncelenmesi, 5. Uluslararası İleri Teknolojiler Sempozyumu (IATS'09), 13-15 Mayıs 2009, Karabük, 2178-2183.

Özmen, G., Orakdöğen, E., \& Darılmaz, K. (2013). Örneklerle SAP2000-V15. İstanbul: Birsen Yayınevi.

Özsoy, A. E., \& Özgen, K. (2005). Perdelerdeki Boşlukların Yatay Ötelenmeye Etkisi. Deprem Sempozyumu Kocaeli 2005, (s. 444-450).
SAP2000, (V16). Integrated Software for Structural Analysis and Design. Computers and Structures, Inc., California, USA.

Türkiye Bina Deprem Yönetmeliği (TBDY)(2018). Afet ve Acil Durum Yönetimi Başkanlığı.

Uçar T., Toumatarı S.G., Ertutar Y., 2014, Çerçeve Düzlemi İçinde Eklenen Perdelerin Betonarme Binaların Yapısal Özelliklerine Etkilerinin İncelenmesi, İleri Teknoloji Bilimleri Dergisi Cilt 3, Sayı 1, 56-68. 